\title{
RADIOIMMUNOASSAY OF HERPES-SIMPLEX AND MEASLES VIRUS ANTIBODIES IN SERUM AND CEREBROSPINAL FLUID OF PATIENTS WITHOUT INFECTIOUS OR DEMYELINATING DISEASES OF THE CENTRAL NERVOUS SYSTEM
}

\author{
Kirsti O. K. Kalimo, R. J. Marttila, B. R. Ziola, Marja-Terttu \\ Matikainen AND M. Panelius \\ The Neurovirology Study Group, Departments of Virology and Neurology, \\ University of Turku, Kiinamyllynkatu 10, 20520 Turku 52, Finland
}

THE investigation of viral antibodies in cerebrospinal fluid (CSF) has recently become important when considering diseases of the central nervous system (CNS). When dealing with acute viral infections of the CNS, detection of an increase in viral antibodies in the CSF may be a more reliable indication of infection than the finding of an increase in serum antibodies alone (Lerner et al., 1972; Kurtz, 1974; MacCallum, Chinn and Gostling, 1974; LeventonKriss, Rannon and Joffe, 1976). Furthermore, in aetiological studies on certain chronic neurological diseases, demonstration of viral antibodies in the CSF is important, especially if production of viral antibody inside the CNS is suspected (Salmi et al., 1972; Salmi, Norrby and Panelius, 1972; Norrby et al., 1974; Cunningham-Rundles et al., 1975; Libiková et al., 1975; Nikoskelainen et al., 1975). A necessary prerequisite for the interpretation of the presence of viral antibodies in CSF, however, is knowledge of CSF viralantibody levels in the population at large.

Detailed study of the distribution of viral antibodies in serum and CSF has been hampered by the relatively low sensitivity of the conventional serological techniques, namely the complement fixation, haemagglutination inhibition, immunofluorescence and neutralisation tests. Usually antiviral antibodies can be demonstrated only in the CSF of patients with acute infectious disorders of the CNS such as encephalitis, meningitis, and myelitis (Lerner et al., 1972; Winchester and Hambling, 1972; Kurtz, 1974; MacCallum et al. 1974; Cappel, Thiry and Clinet, 1975; Carroll and Booss, 1976; Deibel and Schryver, 1976; Leventon-Kriss et al., 1976) or in that of patients with subacute sclerosing panencephalitis (Salmi et al., 1972). In these conditions, the presence of viral antibodies in the CSF may indicate either leakage of antibodies from the serum as a consequence of a blood-brain barrier (BBB) lesion, or local production in the CNS of antibody levels that exceed the detection limit of the serological method used.

The present study was designed to investigate the normal distribution of viral antibodies in serum and CSF and to correlate the serum and CSF antibody

Received 28 Jan. 1977; accepted 7 Apr. 1977.

J. MED. MICROBIOL.-VOL. 10 (1977) 
ratios with serum and CSF total-IgG ratios in patients without infectious or demyelinating diseases of the CNS. The study was made possible by the application of a highly sensitive solid-phase radioimmunoassay (RIA) (Arstila et al., 1977; Kalimo et al., 1977), capable of detecting minute amounts of antibody.

\section{MATERIALS AND METHODS}

Patients. Serum and CSF specimens were obtained from 61 patients attending the Department of Neurology, University of Turku. Only patients without evidence of viral or bacterial CNS infection or demyelinating disease were included in this study. No attempt was made to rule out patients with probable BBB lesions; thus the material included patients with normal and disturbed BBB function. The patients grouped according to diagnosis are shown in table I and their age and sex distribution in table II.

Lumbar puncture was performed by a routine technique and only specimens free from contaminating blood were accepted. Parallel serum specimens were obtained on the same or following day. The specimens were stored at $-20^{\circ} \mathrm{C}$ until used.

Serological tests. The quantitative determination of serum and CSF albumin and IgG concentrations was performed by the single radial immunodiffusion technique (Mancini, Carbonara and Heremans, 1965).

The solid-phase RIA used in this study (Kalimo et al., 1976) was originally developed to detect rubella IgG antibodies. The same method was subsequently used to demonstrate IgG

TABLE I

The 61 patients

\begin{tabular}{l|c}
\hline \multicolumn{1}{c|}{ Diagnosis } & Number of patients \\
\cline { 2 - 2 } Transient ischaemic attacks of brain & 11 \\
Cervical spondylosis & 7 \\
Epilepsy & 7 \\
Basilar artery insufficiency & 6 \\
Carotid thrombosis & 6 \\
Essential tremor & 5 \\
Migraine & 5 \\
Extrapyramidal syndrome & 4 \\
Lumbar disk prolapse & 3 \\
Diabetic neuropathy & 2 \\
Medullar compression & 2 \\
Sequelae after head trauma & 2 \\
Psychosis & 1 \\
\hline
\end{tabular}

TABLE II

Distribution of the patients according to age and sex

\begin{tabular}{|c|c|c|c|c|c|c|c|}
\hline \multirow{2}{*}{$\begin{array}{l}\text { Sex (and number) } \\
\text { of patients }\end{array}$} & \multicolumn{6}{|c|}{ Number of patients aged (years) } & \multirow[b]{2}{*}{ Mean age $\pm S D$} \\
\hline & $>30$ & $30-39$ & $40-49$ & $50-59$ & $60-69$ & $70 \leqq$ & \\
\hline \multirow{2}{*}{$\begin{array}{l}\text { Females (28) } \\
\text { Males (33) } \\
\text { Males and females } \\
\quad(61)\end{array}$} & $\begin{array}{l}2 \\
4\end{array}$ & $\begin{array}{l}2 \\
2\end{array}$ & $\begin{array}{r}6 \\
12\end{array}$ & $\begin{array}{l}7 \\
7\end{array}$ & $\begin{array}{l}4 \\
7\end{array}$ & $\begin{array}{l}7 \\
1\end{array}$ & $\begin{array}{l}55 \cdot 9 \pm 15 \cdot 6 \\
48 \cdot 4 \pm 14 \cdot 6\end{array}$ \\
\hline & 6 & 4 & 18 & 14 & 11 & 8 & $51 \cdot 8 \pm 15 \cdot 4$ \\
\hline
\end{tabular}


antibodies against measles virus antigen (Arstila et al., 1977), capsid and envelope antigens of herpes simplex virus (HSV) and proteins excreted by HSV infected cells (" excreted antigen ") (Kaplan, Erickson and Ben-Porat, 1975; Kalimo et al., 1977). In brief, serial fourfold dilutions of serum or CSF specimens were incubated with viral antigen-coated polystyrene balls in disposable plastic tubes. After incubation at $37^{\circ} \mathrm{C}$ for $1 \mathrm{~h}$, the serum or CSF was removed and the balls were washed twice with $5 \mathrm{ml}$ of tap water. An aliquot of 125I-labelled antihuman-IgG containing 30000 c.p.m. was then added to each tube. After an additional incubation at $37^{\circ} \mathrm{C}$ for $1 \mathrm{~h}$, the radioactive solution was removed and the balls were washed as above. The balls were then transferred to clean plastic tubes and the bound radioactivity was counted in a LKB Wallac 1280 gamma counter.

In the present assays, pig antihuman-IgG (a gift from Orion Diagnostica, Helsinki, Finland) was radiolabelled instead of the previously used sheep antihuman $\gamma$-globulin (Kalimo et al., 1976 and 1977; Arstila et al., 1977). Iodination was done according to Hunter and Greenwood (1962) except that $\mathrm{NaHSO}_{3}$ was omitted as suggested by Krohn, Sherman and Welch (1972). Specific activities ranged from 5 to $20 \mu \mathrm{Ci} \mathrm{per} \mu \mathrm{g}$. The nonspecific binding observed when $125 \mathrm{I}$-labelled pig antihuman-IgG was used was two to three times higher than that found in earlier assays with 125I-labelled sheep antihuman $\gamma$-globulin. This difference was overcome by incubating the antigen-coated polystyrene balls in $2 \%$ normal pig serum for $16 \mathrm{~h}$ at room temperature immediately before incubating with serum or CSF. This pretreatment was used throughout the study.

A positive- and negative-control serum and CSF specimen and a buffer blank were included in each test. The titration end points were obtained from the c.p.m. $\left(\log _{10}\right)$ versus dilution $\left(\log _{2}\right)$ curve of each specimen. The endpoint was that serum or CSF dilution in which the c.p.m. values obtained were three times those of the negative controls.

\section{RESULTS}

The results of the antibody assays are summarised in table III. Serum antibodies against HSV antigens were demonstrated in 57 of the 61 specimens tested. In each positive serum, antibodies were found against all three HSV subunit antigens. With one exception, antibodies against all three HSV antigens were also detected in the CSF of the patients with HSV serum antibody The one exception was a patient with HSV serum antibody and CSF containing low titre antibody against the HSV envelope antigen only. The four patients who had no HSV serum antibodies had no HSV antibodies in their CSF.

Antibodies to measles virus antigen were demonstrated in 59 serum and $47 \mathrm{CSF}$ specimens out of the 61 pairs tested. The $14 \mathrm{CSF}$ specimens with no measles virus antibodies included two from patients without serum antibodies to measles virus and 12 from patients with low serum titres.

As shown in table III, the titres of antiviral serum antibody determined by the solid-phase RIA were high. There were striking differences, however, between the four antigens in terms of their mean antibody titres. The mean titres against the HSV capsid and envelope antigens were 10080 and 20150 respectively, whereas the mean titres to the HSV excreted antigen and to measles antigen were 3100 and 1024 respectively. The RIA IgG-antibody titres of the CSF specimens were, as expected, lower than those of the serum. However, the mean CSF-antibody titres to each of the viral antigens appeared to be in proportion to the corresponding mean titres of the serum specimens.

Also included in table III are the serum and CSF antibody ratios which were calculated by subtracting the CSF antibody titres $\left(\log _{2}\right)$ from the corresponding serum antibody titres $\left(\log _{2}\right)$. The ratios of antibodies to the HSV 
capsid and envelope antigens were almost identical as were those to the HSV excreted and measles virus antigens, but the observed difference in geometric mean ratios in respect of the two pairs of antigens was nearly two-fold.

When the serum to CSF total-IgG ratios (whose mean values are shown in table IV) were compared with the antibody ratios, a positive correlation

\section{TABLE III}

Serum and cerebrospinal fluid (CSF) antibody against herpes-simplex virus (HSV) antigens

(capsid, envelope and excreted) and measles virus antigen in 61 patients with no evidence of infectious or demyelinating disease in CNS

\begin{tabular}{|c|c|c|c|c|c|}
\hline \multirow{3}{*}{ Specimens } & \multirow{3}{*}{$\begin{array}{l}\text { Measurement } \\
\text { or calculation }\end{array}$} & \multicolumn{4}{|c|}{ Entries in respect of antibody to } \\
\hline & & \multicolumn{3}{|c|}{$\underbrace{\mathrm{HSV}}$} & \multirow{2}{*}{$\begin{array}{l}\text { measles } \\
\text { antigen }\end{array}$} \\
\hline & & $\begin{array}{l}\text { capsid } \\
\text { antigen }\end{array}$ & $\begin{array}{c}\text { envelope } \\
\text { antigen }\end{array}$ & $\begin{array}{c}\text { excreted } \\
\text { antigen }\end{array}$ & \\
\hline Serum samples & $\begin{array}{l}\text { Number positive } \\
\text { Mean titre }\left(\log _{2}\right) \pm S D \\
\text { Range }\left(\log _{2}\right) \\
\text { Geometric mean titre }\end{array}$ & $\begin{array}{l}57 \\
13 \cdot 3 \pm 1 \cdot 1 \\
9 \cdot 7-15 \cdot 4 \\
10080\end{array}$ & $\begin{array}{l}57 \\
14 \cdot 3 \pm 1 \cdot 2 \\
10 \cdot 1-16 \cdot 6 \\
20150\end{array}$ & $\begin{array}{l}57 \\
11 \cdot 6 \pm 1 \cdot 2 \\
8 \cdot 0-13 \cdot 8 \\
3100\end{array}$ & $\begin{array}{l}59 \\
10 \cdot 1 \pm 1 \cdot 8 \\
7 \cdot 0-15 \cdot 6 \\
1024\end{array}$ \\
\hline CSF samples & $\begin{array}{l}\text { Number positive } \\
\text { Mean titre }\left(\log _{2}\right) \pm \mathrm{SD} \\
\text { Range }\left(\log _{2}\right) \\
\text { Geometric mean titre }\end{array}$ & $\begin{array}{l}56 \\
4 \cdot 0 \pm 1 \cdot 4 \\
1 \cdot 0-6 \cdot 2 \\
16\end{array}$ & $\begin{array}{l}57 \\
4 \cdot 9 \pm 1 \cdot 6 \\
1 \cdot 0-8 \cdot 5 \\
30\end{array}$ & $\begin{array}{l}56 \\
3 \cdot 0 \pm 1 \cdot 4 \\
0 \cdot 8-6 \cdot 5 \\
8\end{array}$ & $\begin{array}{l}47 \\
2 \cdot 0 \pm 1 \cdot 3 \\
0 \cdot 4-5 \cdot 4 \\
4\end{array}$ \\
\hline \multirow{2}{*}{$\begin{array}{l}\text { Serum and } \\
\text { CSF antibody } \\
\text { ratios }\end{array}$} & Mean $\left(\log _{2}\right) \pm S D$ & $9 \cdot 3 \pm 1 \cdot 0$ & $9 \cdot 4 \pm 1 \cdot 2$ & $8 \cdot 6 \pm 1 \cdot 2$ & $8 \cdot 6 \pm 1 \cdot 2$ \\
\hline & $\begin{array}{l}\text { Range }\left(\log _{2}\right) \\
\text { Geometric mean }\end{array}$ & $\begin{array}{c}5 \cdot 5-11 \cdot 4 \\
630\end{array}$ & $\begin{array}{c}5 \cdot 9-11 \cdot 5 \\
675\end{array}$ & $\begin{array}{c}5 \cdot 7-10 \cdot 5 \\
388\end{array}$ & $\begin{array}{c}5 \cdot 3-11 \cdot 0 \\
388\end{array}$ \\
\hline
\end{tabular}

\section{TABLE IV}

Mean IgG and albumin concentrations in parallel serum and cerebrospinal fuid $(C S F)$ specimens of 61 patients with no evidence of infectious or demyelinating CNS disease

\begin{tabular}{l|cc}
\hline \multicolumn{1}{|c|}{ Specimens } & $\begin{array}{l}\text { IgG } \\
\text { Serum samples }\end{array}$ & $\begin{array}{l}\text { Mean concentrations } \pm \text { SD (with ranges in parentheses) of } \\
\begin{array}{l}10 \cdot 6 \pm 2 \cdot 7^{*} \\
(6 \cdot 2-15 \cdot 3) \\
33 \cdot 9 \pm 21 \cdot 8 \dagger \\
(12 \cdot 0-131 \cdot 0)\end{array} \\
\text { CSF samples }\end{array}$ \\
\hline $\begin{array}{l}\text { Mean serum and CSF ratios } \\
\text { for IgG and for albumin } \\
\text { (with ranges in parentheses) }\end{array}$ & $\begin{array}{l}32 \cdot 7 \pm 9 \cdot 2^{*} \\
(14 \cdot 7-44 \cdot 5) \\
132 \cdot 2 \pm 89 \cdot 5 \dagger\end{array}$ \\
\hline
\end{tabular}

*=Grams per litre. $\dagger=$ Milligrams per litre. 
$(\mathrm{P}<0.001)$ was found. The regression lines are shown in the figure. The serum to CSF antibody ratios were also correlated with the serum to CSF albumin ratios $(P<0.05)$. The age of the patients was inversely related $(\mathrm{P}<0.001)$ to the albumin ratios, but not to the $\operatorname{IgG}$ ratios $(\mathrm{P}>0.05)$. Before making the correlation between age and the serum to CSF ratios of albumin or IgG, 13 patients with evident BBB lesions (albumin ratio $<150$ ) were excluded.

In each instance where antibody was present in serum but not in CSF, there appeared to be a low serum-antibody level and a normal or high ratio between serum and CSF IgG. For example, one patient had serum antibodies to all three HSV antigens, but CSF antibody against only the HSV envelope antigen. In this patient the ratio between HSV envelope antibody in serum and CSF was $11.5\left(\log _{2}\right)$ and the serum to CSF total-IgG ratio was also high (467); since the serum antibody titres to both the capsid and excreted HSV antigens fell below 11.5 [11.3 and 9.0 $\left.\left(\log _{2}\right)\right]$, it was not surprising that these antibodies could not be detected in the CSF. Similarly, 12 patients without

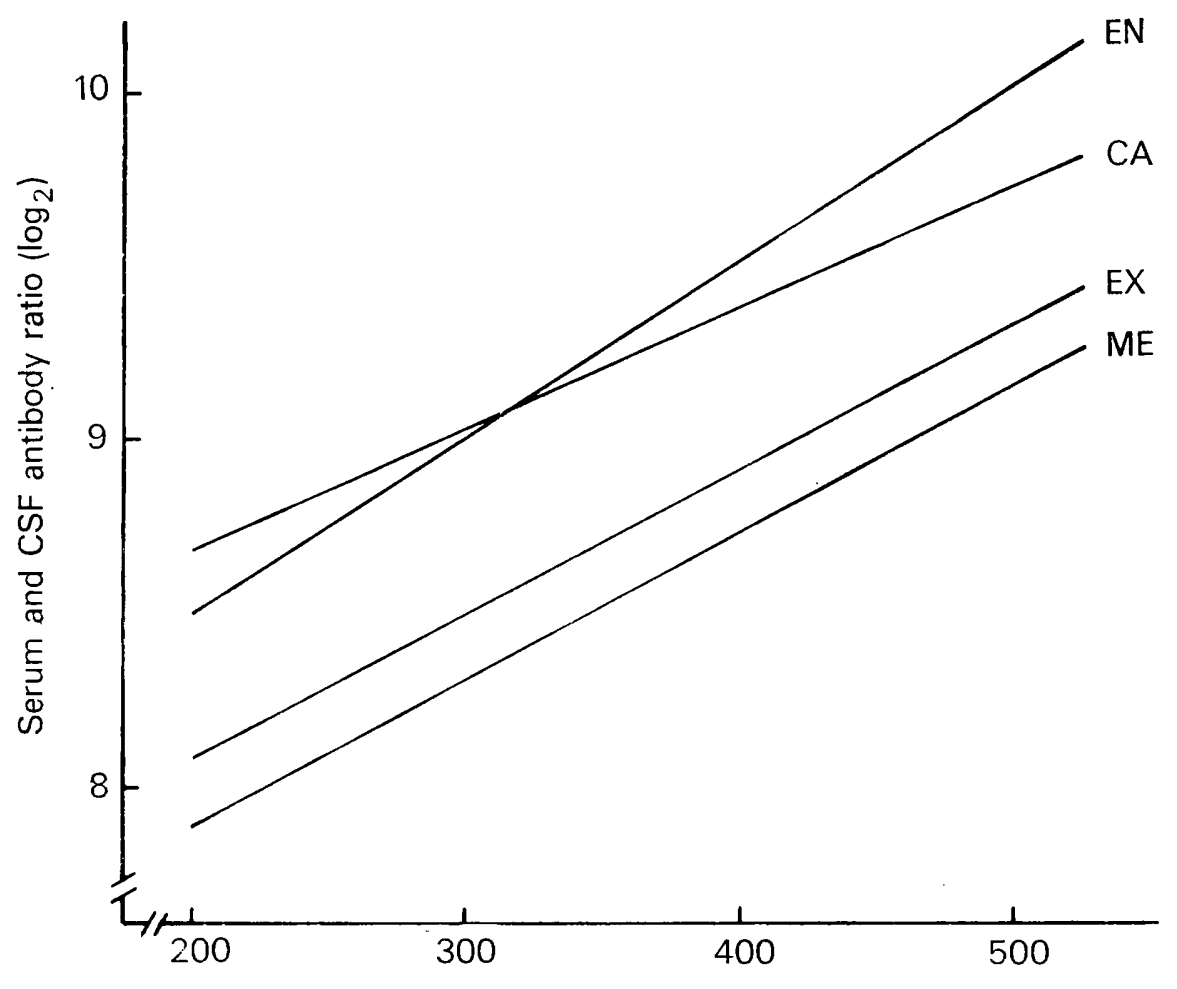

Serum and CSF IgG ratio

FIGURE

Correlation of serum to CSF antibody ratios $\left(\log _{2}\right)$ with serum to CSF total-IgG ratios. The correlation coefficients $(r)$ for antibodies against the three herpes-simplex virus antigens [envelope $(E N)$, capsid $(C A)$ and excreted $(E X)]$ and against measles virus antigen $(\mathrm{ME})$ are $0 \cdot 62,0 \cdot 49$, 0.50 and 0.54 respectively.

J. MED. MICROBIOL.-VOL. 10 (1977) 
CSF antibodies to measles virus all had low serum-antibody titres to measles antigen, ranging from $7 \cdot 0$ to $8.8\left(\log _{2}\right)$. At the same time, the serum to CSF IgG ratio of these 12 patients was higher in every case than the serum measles antibody titre.

\section{Discussion}

The principal purpose of this study was to investigate the distribution of viral antibodies in serum and CSF, particularly in patients without infections of the CNS, by means of a highly sensitive solid-phase RIA. The results showed that viral antibodies can be demonstrated in the CSF of certain patients without infection of the CNS. In respect of both HSV and measles virus, ratios between antibody in serum and CSF were closely related to similar ratios based on measurements of total IgG; thus, detection of antibodies in CSF was directly dependent on the serum antibody level and on the ratio between serum and CSF IgG. It seems likely that antibodies against other viruses may behave in a similar manner.

The serum to CSF antibody ratios were correlated with the albumin ratios $(\mathrm{P}<0.05)$. A similar correlation was found between the total IgG ratios and the albumin ratios in patients with no evidence of BBB lesions (albumin ratios >150); this supports the earlier findings of Ganrot and Laurell (1974). An inverse relation $(\mathrm{P}<0.001)$ was found between the age of the patients and the albumin ratios, suggesting that the lower molecular-weight albumin penetrates a BBB with partial or minute lesions more easily than does the higher molecular-weight IgG. Thus, the serum to CSF albumin ratio appears to be a good indicator of a coexisting BBB lesion while the serum to CSF total-IgG ratio would seem more useful in evaluating disturbed antibody ratios.

Several conclusions can be drawn from the present study. Most individuals with serum containing detectable viral antibodies can be shown to possess similar antibodies in their CSF, provided that a highly-sensitive assay technique is used. Thus, the previous occurrence of a viral infection of the CNS cannot be presumed merely on the demonstration of CSF viral antibodies; a coexistent BBB lesion may result in CSF antibody levels that exceed the lower sensitivity limit of even conventional serological methods. Determinations of serum and CSF IgG (or other classes of immunoglobulin) and albumin must be carried out to calculate the serum to CSF ratios. Such ratios in respect of total IgG and virus specific antibody would, if low, indicate local antibody production in the CNS (Carroll and Booss, 1976) provided that coexisting BBB lesions can be excluded. Total protein concentrations in serum and CSF may help in detecting a BBB lesion, but these alone are insufficient to enable further conclusions about the serum to CSF IgG ratio to be drawn. If local production in the CNS of a certain viral antibody is suspected in acute or slow viral infections, antibody to a virus unlikely to be involved in CNS infection should be assayed. The serum to CSF antibody ratio for such a virus may constitute the most convincing evidence of the integrity of the BBB. Finally, the normal 
antibody ratio must be determined separately for each antigen, viral or otherwise, as variations in the sensitivity of assay methods can result in different numerical values for the serum to CSF antibody ratios. This is clearly shown by the nearly two-fold difference in antibody ratios in respect of the viral antigens used in this study. Endpoint determinations in the solid-phase RIA depend on negative-sample background levels; it is not surprising that some variation in sensitivity was observed, as the non-specific background binding is not exactly the same for each antigen tested. Less sensitive techniques than RIA for the detection of viral antibodies in CSF can be used for diagnostic purposes provided that their sensitivity thresholds are first established by determining the serum to CSF IgG ratios of enough " normal" patients. Only then can reliable conclusions be drawn about disturbed serum to CSF antibody ratios.

\section{SUMMARY}

A solid-phase radioimmunoassay was used to detect IgG antibodies against herpes-simplex virus antigens (capsid, envelope and excreted) and against measles virus antigen in serum and cerebrospinal fluid (CSF) specimens of 61 patients with no evidence of infectious or demyelinating disease of the central nervous system. Quantitative determinations of IgG and albumin in serum and CSF were also performed.

Of the 61 serum and $61 \mathrm{CSF}$ samples tested, 57 and 56 respectively contained antibodies against subunit antigens of herpes simplex virus. Antibody against measles virus was found in 59 serum and $47 \mathrm{CSF}$ specimens.

A positive correlation $(\mathrm{P}<0.001)$ was found between each of the four serum to CSF antibody ratios and the serum to CSF total IgG ratios. This indicated that the distribution of antiviral $\mathrm{IgG}$ antibodies in serum and CSF normally follows the distribution of total IgG. The ratios between viral antibody in serum and CSF were also correlated with albumin ratios $(P<0.05)$. An inverse relation $(\mathrm{P}<0.001)$ was found between the age of the patients and their serum to CSF albumin ratios, but not their IgG ratios, suggesting that the albumin ratio is a useful indicator of a blood brain barrier lesion and that the IgG ratio should be used in evaluating disturbed antibody ratios.

This study was supported by grants from the Acadamy of Finland, Medical Research Council. The excellent technical assistance of Mrs Marita Maaronen and Miss Marjut Kallila is gratefully acknowledged. B. R. Ziola is the recipient of a Centennial Fellowship from the Medical Research Council of Canada.

\section{REFERENCES}

arstila, P., Vuorimaa, T., Kalimo, K. O. K., Halonen, P., Viluanen, M., Granfors, K. AND Tolvanen, P. 1977. Solid-phase radioimmunoassay for IgG and IgM antibodies against measles virus. J. gen. Virol., 34, 167.

CAPPEl, R., ThIRY, L. AND Clinet, G. 1975. Viral antibodies in the CSF after acute CNS infections. Archs Neurol., 32, 629.

Carroll, J. F. AND Booss, J. 1976. Cerebrospinal fluid IgG level in herpes simplex encephalitis. J. Am. med. Ass., 236, 2092. 
Cunningham-Rundles, C., Jersild, C., Dupont, B., Posner, J. B. And Good, R. A. 1975. Detection of measles antibodies in cerebrospinal fluid and serum by a radioimmunoassay. Scand. J. Immun., 4, 785.

DeIBEL, R. AND SCHRYVER, G. D. 1976. Viral antibody in the cerebrospinal fluid of patients with acute central nervous system infections. J. clin. Microbiol., 3, 397.

Ganrot, K. AND Laurell, C-B. 1974. Measurement of IgG and albumin content of cerebrospinal fluid, and its interpretation. Clin. Chem., 20, 571.

Hunter, W. M. and Greenwood, F. C. 1962. Preparation of iodine-131 labelled human growth hormone of high specific activity. Nature, Lond., 194, 495.

Kalimo, K. O. K., Marttila, R. J., Granfors, K. and Viljanen, M. K. 1977. Solid-phase radioimmunoassay of human immunoglobulin $M$ and immunoglobulin $G$ antibodies against herpes simplex virus type 1 capsid, envelope, and excreted antigens. Infect. Immun., 15, 883.

Kalimo, K. O. K., Meurman, O. H., Halonen, P. E., Ziola, B. R., Viljanen, M. K., Granfors, K. AND ToIvANEN, P. 1976. Solid-phase radioimmunoassay of rubella virus immunoglobulin $\mathrm{G}$ and immunoglobulin $\mathrm{M}$ antibodies. J. clin. Microbiol., 4, 117.

Kaplan, A. S., Erickson, J. S. AND Ben-Porat, T. 1975. Synthesis of proteins in cells infected with herpesvirus. X. Proteins excreted by cells infected with herpes simplex virus types 1 and 2 . Virology, 64, 132.

Krohn, K., Sherman, L. AND Welch, M. 1972. Studies of radio-iodinated fibrinogen. I. Physicochemical properties of the ICI, chloramine-T, and electrolytic reaction products. Biochim. biophys. Acta., 285, 404.

KuRTZ, J. B. 1974. Specific IgG and IgM antibody responses in herpes-simplex-virus infections. J. med. Microbiol., 7, 333.

Lerner, A. M., Lauter, C. B., Nolan, D. C. and Shippey. M. J. 1972. Passive hemagglutinating antibodies in cerebrospinal fluids in Herpesvirus hominis encephalitis. Proc. Soc. exp. Biol. Med., 140, 1460.

LeVENTON-Kriss, S., RANNon, L. AND Joffe, R. 1976. Fluorescence and neutralizing antibodies to herpes simplex virus in the cerebrospinal fluid of patients with central nervous system diseases. Israel J. med. Sci., 12, 553.

Libíková, H., Pogády, J., Wiedermann, V. and Breier, S. 1975. Search for herpetic antibodies in the cerebrospinal fluid in senile dementia and mental retardation. Acta virol., Prague, 19, 493.

MacCallum, F. O., Chinn, I. J. and Gostling, J. V. T. 1974. Antibodies to herpes-simplex virus in the cerebrospinal fluid of patients with herpetic encephalitis. J. med. Microbiol., $7,325$.

Mancini, G., Carbonara, A. O. and Heremans, J. F. 1965. Immunochemical quantitation of antigens by single radial immunodiffusion. Immunochemistry, 2, 235.

Nikoskelainen, E., Nikoskelainen, J., Salmi, A. A. And Halonen, P. E. 1975. Virus antibody levels in the cerebrospinal fluid from patients with optic neuritis. Acta neurol. Scand., 51, 347.

Norrby, E., Link, H., Olsson, J-E., Panelius, M., Salmi, A. and Vandvik, B. 1974. Comparison of antibodies against different viruses in cerebrospinal fluid and serum samples from patients with multiple sclerosis. Infect. Immun., 10, 688.

Salmi, A. A., Norrby, E. and Panelius, M. 1972. Identification of different measles virus-specific antibodies in the serum and cerebrospinal fluid from patients with subacute sclerosing panencephalitis and multiple sclerosis. Infect. Immun., 6, 248.

Salmi, A. A., Panelius, M., Halonen, P., Rinne, U. K. and Pennttinen, K. 1972. Measles virus antibody in cerebrospinal fluids from patients with multiple sclerosis. Br. med.J., $1,477$.

Winchester, J. S. AND Hambling, M. H. 1972. Antibodies to measles, mumps, and herpes simplex virus in cerebrospinal fluid in acute infections and post-infectious diseases of the central nervous system. J. med. Microbiol., 5, 137. 